\title{
Determinants of Lending Behaviour Of Commercial Banks: Evidence From Nigeria, A Co-Integration Analysis (1975-2010)
}

\author{
Olusanya, Samuel Olumuyiwa ${ }^{1}$, Oyebo Afees Oluwatosin ${ }^{2}$, Ohadebere \\ Emmanuel Chukwuemeka ${ }^{3}$, \\ Lecturer Lagos State University External system, Economics Department. \\ Lecturer Lagos State University External system Marketing Department. \\ Marketing Department Pension Officer, Lagos State Pension Commission \\ Lecturer Lagos State University External system Banking And Finance Department
}

\begin{abstract}
The research study takes a look at determinants of lending behaviour of commercial banks in Nigeria: a Co-integration analysis between 1975 to 2010. However, the study make use of secondary data and series of Econometrics techniques were adopted, to justify the long run relationship between Commercial bank and its lending behaviour over the period of analysis. More over, the study investigates the level of commercial banks loan advances in Nigeria and to also examine those various determinants of commercial banks lending behavior in Nigerian. More so, the model used is estimated using Nigerian commercial bank Loan and advances $(L O A)$ and other determinants such as Volume of deposits (Vd), annual average exchange rate of the naira to dollar (Fx) for the period of thirty-seven (37) years, Investment Portfolio (Ip), Interest rate (lending rate) (Ir), Gross domestic product at current market price $(G d p)$ and Cash reserve requirement ratio $(R r)$. However, the model result reveals that there is positive relationship between Loan and advances and Volume of deposits, annual average exchange rate of the naira to dollar, Gross domestic product at current market price and cash reserve requirement ratio except Investment portfolio and Interest rate (lending rate) that have a negative relationship. It was also revealed from the result that there is a long run relationship between Loan and advances and all the explanatory variables in the model and this shows that commercial bank has a lot of impact of their lending behaviour. Finally the study recommend and conclude that commercial bank should endeavour to create more deposit in other to improve their lending behaviour and should enforce the most easily realizable policies and good credit management in every situation.
\end{abstract}

Key words: Investment Portfolio, Lending rate, Deposits, Exchange rate, Cash reserve, Gross domestic Product and Loan and advances.

\section{Introduction}

In human societies, since the evolution of money, there have always existed those who possess money in excess of their immediate needs (surplus economic unit) and those whose current possession cannot finance their economic activities (deficit economic unit). The realization by the surplus economic unit that their excess can be used beneficially to meet the shortfalls experienced by the deficit economic unit led to the introduction of a credit system. This system was initially characterized by lenders (surplus units) and borrowers (deficit unit) having to search out themselves and deal directly... Direct financing (Akpan, 2009, Akpaniko and Acha, 2010). Indirect financing includes the aggregation of deposits from various households, firms and government by commercial banks for lending to the deficit uni; , the repayment of the loan is made to the bank which also stands ready to redeem deposits withdrawals by the surplus unit. And this is the basis for this thesis.

This lending could be on short, medium and/or long term basis is a major service rendered by the commercial bank to their customers which includes: individual, firms and government to aid their economic activities for the development and growth of the national economy. Thus, banks lending activities generate economic growth through resources provision for real investment (Mckinnon, 2005). This brought about the acceptance and implementation of financial liberalization by many developing economies including Nigeria.

Inspite of the well known liberalization and similar policies, economists remain divided in their opinion concerning the relationship between Nigerian commercial banks loan advance (LOA) and the determinants of their lending behavior.

Commercial banks are the most important savings mobilization and financial resources allocation institution. Eventually, those roles make them an important phenomenon in economic growth and development. In order for them to perform these roles, it must be realized that banks have the potential, scope and prospects of financial intermediation. Therefore, they must bear in mind the three (3) principles guiding their operation which are: profitability, liquidity and solvency. And the determinants of the commercial bank lending behavior includes: the Volume of deposits (Vd) their Investment portfolio (Ip), the presiding interest (lending) rate (Ir), 
Cash reserve requirement ratio ( $\mathrm{Rr}$ ), annual average exchange rate of the naira to dollar $(\mathrm{Fx})$ and Liquidity ratio (Lr) .

Though the lending practices of banks were strictly regulated under the close surveillance of the banks supervisory bodies, but the Structural Adjustment Programmed (SAP) introduced in 1986 brought about some relaxation of the stringent rules guiding banking practices. And the Bank and Other Financial Act Amendment (BOFIA) 1998 required banks to report large amount borrowing to the CBN. Other banks enectement stipulated that the bank loans should be directed to preferred sectors of the economy (manufacturing, agriculture and power and steel) in other to enhance economic growth and development.

But considering all these regulation, banks resorted to prudential guidelines to avoid failures and achieve maximum profitability in their lending activities. Though, these depend on the type of bank, the capital base, deposit base and its density, the credit guidelines issued periodically by controlling authority, the banks' internal policies and advances accounts for the highest percentage of the total assets of the bank. The commercial banks in Nigeria need to understand how to manage these huge assets in terms of loans and advances; for them to balance their main objectives of liquidity, profitability and solvency. Thus lending must be handled effectively for the banks to remain attractive and retain their customers.

The commercial banks lending has significantly played crucial roles in igniting industrialization in every economy, by facilitating the mobilization of capital which oils the wheels of economic production. And that well functioning banks spur technological innovations by identifying and funding entrepreneurs assessed to have brighter chances of successful implementing innovative products and production process.

But the sound and viable functioning of commercial banks is adversely affected by the choice of certain policy instruments for the regulation of banking operations. Such includes a rigidly administered interest rate structure, Directed credit, unremunerated reserve requirements and stabilizing liquidity control measures, the volume of cash in the banks voult also determines its ability to grant advances. Since cheques have to be met in cash in many cases, they should stock reasonable quantity of cash to meet customers demand. Moreover the days of armchair (cheap profit) banking are over and that the increasing trend in bad debts and absence of basic business corporate advisor services in most commercial banks, suggest the apparent lack of use of effective lending and credit administrative techniques in these banks.

Despite the fact that commercial banks in Nigeria witnessed the era of impressive profitability, characterized by high competition, huge deposits and varied investment opportunities, some tend to disregard the fact that their administration require considerable skill and dexterity on the part of their management. Where a bank grants advances in excess of its chasing ability, the bank soon runs into difficulty in meeting its customer's cash drawings. The same also applies to situation where loans and advances are give out by commercial bank without adequate or comisorable collateral and backups. Non-servicing of loans also reduce the profitability and liquidity levels of the affected banks. The recent bank reformation of 2009 revealed a lot in this line. Finally the objectives of the study to investigate the level of commercial banks loan advances in Nigeria and to also examine those various determinants of the commercial banks lending behavior

\section{Literature Review and Theoretical Framework}

\section{Literature review}

Most studies divide the determination of commercial banks behaviors into two (2) categories that is: internal and external factors. The internal determinants includes: profitability which are within the control of the bank management could be broadly classify into two: financial statement variables and non financial statement. By financial: it refers to those items in the balance sheet and income statement. And the non financial variables have no direct relationship to the financial statement. Example: number of branches, states of banks (ltd or full service branch, unit or multiple branches, location or size of bank) Haron sudin (2004).

External factors are those factors that are not to be controlled by the bank management e.g Competition, regulation, market share, ownership, money supply, inflation. So much have been reviewed in terms of lending activities of various commercial banks, some opinions discussed on the factors responsible for banks willingness to extend much credit to some sector of the economy, while some deliberated on the effect of such extension of credits on productivity and output. Most of these earlier studies agree on the fact that it is logical for banks to have some basic lending principles to act as a check in their lending activities. It is necessary to illuminate and consider some factors that economists and professionals have proposed as virtually significant in explaining the determinants of commercial banks lending behaviour.

"A banks ability to grant further advances in checked by the availability of cash in its vault" asserted Ituwe (1983), since customers|' drawing are paid in two ways, either in cash or through banks accounts. Since cheques have to be met in cash in many cases. Commercial banks, therefore have to stock reasonable quality of cash to meet customers' demand. The position that "a major regulation affecting commercial bank lending in Nigeria in the restriction on the amount of interest they are allowed to pay on deposits in an effort to attract additional depositors and the interest they charge on their fund base activities" Usman (1999). And Goldfeld 
and Chandler (1980) claimed that "commercial banks must pay more attention to liquidity than many other types of Financial institutions such as life insurance companies. This results from the high turnover of their debt liabilities. A large part of the gross out payments by a bank is met from current gross receipt of funds in the normal course of business

Toni Uhomoibhi (2008) investigated the determinants of bank profitability macroeconomic evidence from Nigeria seeking to econometrically identify significants using a panel data set comprising 1255 observations of 154 banks over a period of 1980-2006, the indices over the same period regression result reveal that interest rate, inflation, monetary policy and exchange rate regime, significant macroeconomic determinants of banks profitability in Nigeria banking sector development, stock market development and financial structure are insignificant and the relationship between corporate tax policy and bank profitability in Nigeria is inconclusive.

In Ezirim's (2005) view, "Bank lending decision generally are fraught with a great deal of risks, which calls for great deal of caution and tact in this aspect of banking operations. The success of lending activity to a great extent therefore, lies on the part of the credit analysts to carry out good credit analysis, presentations, structuring and reporting.

However Samad (2004) examined the study of Bahran's commercial banks performances during 19942001. The main focus of the study was to examine empirically the performance of Bahrain's commercial banks with respect to credit (loan), liquidity and profitability during the period. By applying students', t-test to the financial measure. It was shown that commercial banks liquidity performance is not at par with the banking industry. That is commercial banks are relatively less profitable and less liquid as expected. Although Chizea (1994) asserted that, "there are certain aspects of fiscal and monetary policies which could affect the decision of the discerning and informed public to patronize the bank and the lending behaviour of commercial banks. Paramount amongst these measures is what could be called the interest rate disincentives. Interest rates have been so low in the country that they are negative in real terms. As inflation increased, the purchasing power of money lodged in deposit accounts reduce to the extent that savers per force pay an inflation tax. There is also the fear that the hike in interest rates would increase inflations rates and make a negative impact on the rate of investment. Thus, on the above, Naceur and Goaid (2010) investigated the determinants of commercial banks interest margin and profitability" (evidence from Tunisia). The study received the impact of banks characteristics, financial structure and macroeconomic indicators on banks net interest margin and profitability in Tunisia banking sector for the period of 1980-2000. It shows that individual bank characteristic explains a substantial part of the within country variation in bank interest margin and net profit. High net interest margin and profitability tend to be associated with banks that holds a relatively high amount of capital and with large overheads size is found to impact negatively on profitability which implies that Tunis banks are operating above their optimum level.

'The mandatory interest rate according to William (2009) will result to a near shut down in lending ratio volume to any bank with major credit concern because, new policy ensures that only the highest quality borrowers have access to a new bank credit within the year. But, according to Ojo (1999), in a study on "roles and failure of financial intermediation by banks in Nigeria" revealed that commercial banks can lend on medium and short term basis without necessarily jeopardizing their liquidity. If they must contribute meaningfully to the economic development, the maturity pattern of their loans should be on a long term nature rather then of short term period. And Davis and Zhu (2005) examined the study of commercial property prices and bank performance during the 1989-2002 period. This paper seeks to fill the gap by undertaking an extensive analysis of a sample of 904 banks worldwide. It seeks to assess the effect of changes in commercial property prices on bank behaviour and performances in 15 industrialized economies. The result of this study suggest that commercial property price tend to be positively associated with bank lending and profitability, negatively associated with banks' net interest margin, bad loan ratios. Such impact exists even when conventional independence variable determining banks performance are included as controls.

Although Olokoya (2011) claimed in the study on "the common determinants of commercial banks lending behaviour", in Nigeria which aimed to test and confirm the effectiveness of these factors/variables. It reveals that there exists functional relationship between the variables. From the regression analysis, the model was found to be significant and its estimators turned out as expected and it was discovered that commercial banks have greatest impact on their lending behavior. And suggested that commercial banks should focus on mobilizing more deposits, as it will enhance their lending performance through the formulation of critical, realistic and comprehensive strategies and financial plans. But Grupta (1970), in his study of personal savings in developing countries argued that 'high real interest rate increases savings' while a contrary view opined by Ajayi (1978), in his study concludes that savings deposits rates in a deregulated regime is not significant in explaining the demand for savings.

Though Acha (2011), probed into 'the effect of banks financial intermediation on economic growth' on a time frame of 1980-2008, adopting the Granger causality test to ascertain the relationship that exist between 
savings mobilization and credit on one hand and economic growth on the other. Acha's study could not identify any significant causal relationship between the variables. Bhattacharya and Thakor (1993), Mishkin \& Eaking (1998); Buckle \& Thompson (1998) and Saunder \& Cornett (2006) Along with Diamond and Dybvig (1983) confirmed the fact that a financial intermediary is able to hold high risk, long term claims issued by borrowers and finance this by issuing low risk and short term deposit - a process known as qualitative asset transformation (QAT) by opining that '...banks provide better risk sharing among agents who need to consume at different (random) times". This liquidity to them provides the rationale for the existence of banks and by extension financial intermediation.

Linking this with the veiws of Adedoyin and Shobodun (1991) that, "lending is undoubtedly the heart of banking business. Therefore, its administration requires considerable skill and dexterity on the part of the bank management while a bank is irrevocably committed to pay interest and deposits, it mobilized from different sources. The ability to articulate loanable avenue where deposit funds could be placed to generate reasonable income, maintain liquidity and ensure safety requires a high degree of pragmatic policy formulation and application.

Osayameh (1991) supported this veiw by stressing that 'the days of arm| chain banking are over, and that the increasing trend in bad debts and absence of basic business corporate advisor services in most Nigerian commercial banks, suggest an apparent lack of use of effective lending and credit administration technique in these banks.

\section{Theory of multiple lending}

\section{Theoretical Framework}

It is found in literature that banks should be less inclined to share lending (loan syndicate0 in the presence of well developed equity markets and after a process consolidation. Both outside equity; and mergers and acquisition increases banks lending capacity, thus reducing that need of greater diversification and monitoring through share lending. (Carletti et al 2006; Ongene \& Smith, 2000; Karet et al, (2004); Dgreyse et al, (2004). This theory has a great implication for banks in Nigeria in the 2005 consolidation exercise and the recent 2009 reformation exercise in the industry.

\section{Firm Characteristics theories.}

These theories predict that the number of borrowing relationships will be decreasing for small high quality informationally opaque and constraints firms, other things been equal. (Godlewski \& Ziane, 2008)

\section{Credit market theory}

A model of the neoclassical credit market postulates that, 'the storms of credits clear the market'. If collateral and other restrictions (covenants) remain constant, the interest rate is the only price mechanism with an increasing demand for credit and a given customer supply, the interest rate rise and vice versa. It is thus believed that the higher the failure risk of borrower, the higher the interest premium ( Ewert et al, 2000).

\section{Hold up and soft budget constraint theories}

Banks choice of multiple banks lending in terms of two inefficiencies affecting exclusive bank from relationship namely: the hold up and the soft budget constraint problems. According to the hold up literature, sharing lending avoids the expropriation of informational rents. This improves firms incentives to make proper investment choices and in turn it increases banks profits (Von Thadden 2004, Padilla and Pagano 1997). As for the soft budget constraint problem, multiple bank lending enables banks not to extend further inefficient credit, thus reducing firms strategic problem, multiple bank lending enables banks not to extend further inefficient credit, thus reducing firms strategic defaults. Both of these theories consider multiple banks lending as a way for banks to commit towards entrepreneurs and improve their incentives. None of them however addresses how multiple bank lending affects banks incentives to monitor, and thus can explain the apparent discrepancy $b / w$ the widespread use of multiple bank lending and the importance of bank monitoring. Carlettic el al (2006) opined that when one considers. When one considers explicitly banks incentives monitor, multiple bank lending may become an optimal for banks with limited lending capacity to commit to high monitoring levels. Despite involving free riding and of efforts, sharing lending allows banks to expand the number of loans and achieve greater diversification. This mitigates the agency problem between banks and depositors, and it improves banks monitoring incentives. Thus differently from the classical theory of banks as delegated monitors, their paper suggested that multiple bank lending may positively affect overall monitoring and increase firms futures profitability. 


\section{Loan Pricing Theory.}

Banks cannot always set high interest rates. Eg. Trying to earn maximum interest income Banks should consider the problems of adverse selection and moral hazards since it is very difficult to forecast the borrower type at the start of the banking relationship (Stiglitz and Weiss, 1981). If banks set interest rates too high, they may induce adverse selection problems because high risk borrowers are willing to accept these high rates. Once these borrowers receive the loans, they may develop moral hazard Behaviour or so called borrower moral hazards since they are likely to take an highly risky projects or investments (Chodecal 2004). From the reasoning of Stiglitz and Weiss, it is usual that in some cases, we may not find that the interest rate set by bank is commensurate with the risk of the borrowers.

\section{Monetary circuit theory}

The monetary circuit theory is a heterodox theory of monetary economist, particularly money creation, often associated with the post Keynesian school that Milton Friedman, Pigon and others. It holds that money is created endogenously by the banking sector, rather then exogenously by central bank lending. It is also referred to as a theory of endogenous money. It stipulates that the economy creates money itself rather than government creating money through the $\mathrm{CBN}$. Banks and other financial firm are modeled separately by this ciruitism.

\section{Circuitist Model}

Circuitist model is easily understood in terms of familiar bank accounts and debit cards or credit card transaction. Bank deposit are just an entry in a bank account book (not specie bills and coins), and a purchase subtracts money from the buyer's account with the bank and adds it to the sellers account with the bank.

\section{Transactions}

Circutism distinguishes between hard money, it is the money that is exchangeable at a give rate for some commodity such as gold and credit money. It considers credit money created by commercial banks as primary rather than derived from central bank money-credit money drives the monetary system, it does not claim that all money is credit money, though money is a commodity. In circuitism, a monetary transaction is not bilateral transaction (between buyer and seller) but rather triparitite transaction between buyer, seller and bank. Rather than buyer handling over a physical good in exchange for their purchase, instead, there is a debit to their account at a bank, and a corresponding credit to the sellers account. That is precisely what happened in credit card or debit card transactions and in the circuitist account.

\section{Money Creation.}

Under this theory credit money is created by a loan extension such loan needs to be backed by CBN Money but it is created from the promise (Credit) embodied in the loan, not from the lending or relending of central bank money. When the loan is repaid, with interest the credit money of the loan is destroyed but reserves (equal to the interest) are created the profit from the loan.

In practice, commercial banks extend time of credit to Companies-a promise to make a loan. This promise is not considered money for regulatory purposes, and banks need not hold reserves against it, but when the line is tapped (and a loan extended). Then bona-fide credit money is created, and reserves must be found to match it, in this case, credit money precedes reserves. In other words, making loans pulls reserves in instead of reserves being pushed out as loans which are assumed by the mainstream model.

\section{MODEL SPECIFICATION}

\section{Methodology}

$\mathrm{LOA}=\mathrm{f}(\mathrm{Vd}, \mathrm{Fx}, \mathrm{Ip}, \mathrm{Ir}, \mathrm{Gdp}, \mathrm{Rr}, \mathrm{Lr}, \mathrm{Z})$

Where $\mathrm{z}$ contains other variables not explicitly includes in the model. The explicit form of equ (i) above is shown as follows:

LOA $=$ loan and advances

$\mathrm{Vd}=$ volume of deposits

Fx = Annual Average Exchange Rate of the Naira to Dollar

Ip $=$ Investment portfolio

Ir $=$ Interest Rate (lending rate)

Gdp $=$ Gross domestic Product at Current market price.

$\mathrm{Rr}=$ cash reserve requirement ratio

$\mathrm{Lr}=$ Liquidity ratio

$\mathrm{U}=$ error term controlling for unit specific residual in the model

$a_{0}=$ intercept of the regression line 
ai's $(i=1-5)=$ coefficient estimated and their appriori expectations wrere as follows: $a_{1}, a_{2}$, a5 and $a_{6}>0$ while $a_{3}$ and $\mathrm{a}_{4}<0$.

Where $\mathrm{z}$ contains other variables not explicitly includes in the model. The explicit form of equation (i) above is shown as follows:

$\mathrm{LOA}=\mathrm{a}_{\mathrm{o}}+\mathrm{a}_{1} \mathrm{Vd}$

$\mathrm{LOA}=\mathrm{aO}+\mathrm{a}_{2} \mathrm{Fx}$

$\mathrm{LOA}=\mathrm{ao}+\mathrm{a}_{3} \mathrm{Ip}$.

$\mathrm{LOA}=\mathrm{aO}+\mathrm{a}_{4} \mathrm{Ir}$.

$\mathrm{LOA}=\mathrm{ao}+\mathrm{a}_{5} \mathrm{Gdp}$

$\mathrm{LOA}=\mathrm{ao}+\mathrm{a} 6 \mathrm{Rr}$.

$\mathrm{LOA}=\mathrm{ao}+\mathrm{a} 7 \mathrm{Lr}$

Therefore, if equation 2 to 8 is added together, it becomes;

$\mathrm{LOA}=\mathrm{a}_{\mathrm{o}}+\mathrm{a}_{1} \mathrm{Vd}+\mathrm{a}_{2} \mathrm{Fx}+\mathrm{a}_{3} \mathrm{Ip}+\mathrm{a}_{4} \mathrm{Ir}+\mathrm{a} 5 \mathrm{Gdp}+\mathrm{a} 6 \mathrm{Rr}+\mathrm{a} 7 \mathrm{Lr}+\mathrm{U}$

Where:

\section{Unit Root Test}

Prior to estimation, we shall subject the data to vigorous tests in order to establish their adequacy as regards stationarity. The need to determine whether time-series data are stationary overtime underscores the importance of unit root test. The test in which the order to integration of each series employed is determined. The determination of each series is necessary for co-integration and indeed for error correction model, simply because each series involved in the estimation of a model must be integration of the same order (Engle and Granger 1987). A time - series is said to be stationary if it exhibits white noise. It implies that the series is integrated of order zero, or at level $\mathrm{X} \sim(\mathrm{d})$.

The Augmented Dickey-Fuller (ADF) test is adopted in this research to determine the order of integration and is stated as follows:

$\Delta \mathrm{Yt}=\mathrm{b}_{1}+\mathrm{b}_{2 \mathrm{t}}+\delta \mathrm{Y}_{\mathrm{t}-1}+\mathrm{a}_{\mathrm{i}} \Sigma \Delta \mathrm{Y}_{\mathrm{t}-1}+\varepsilon_{\mathrm{t}}$

Where $\varepsilon_{\mathrm{t}}$ is a white noise error term and where $\Delta \mathrm{Y}_{\mathrm{t}-1}=\left(\Delta \mathrm{Y}_{\mathrm{t}-1}+\Delta \mathrm{Y}_{\mathrm{t}-2}\right), \Delta \mathrm{Y}_{\mathrm{t}-2}=\left(\Delta \mathrm{Y}_{\mathrm{t}-2}+\Delta \mathrm{Y}_{\mathrm{t}-3}\right)$, etc. the number of lagged difference terms to include is often determined empirically, the idea being to include enough terms so that the error term is serially uncorrelated.

\section{Co-integration Test}

The co-integration technique allows for the estimation of a long-run equilibrium relationship. Simply put, one can argue that various non-stationarity time series are co-integrated when they are linear combination are stationary. Stationary derivations from the long run are allowed in the short run. Economically speaking two variables can only be co-integrated if they have long-term or equilibrium relationship between them. The cointegration technique was pioneered by Engle and Granger (1987) and extended by Johansen (1990). Granger notes, "A test for co-integration can be thought of as a pre test to avoid 'spurious regression' situation. We adopt the Johansen procedure, which is stated as follows:

$\Delta \mathrm{U}_{\mathrm{t}}=\beta_{0}+\delta \mathrm{U}_{\mathrm{t}-1}+\alpha \Sigma \Delta \mathrm{Y}_{\mathrm{t}-1}+\varepsilon_{\mathrm{t}}$

The method that is adopted for testing co-integration is the co-integrating regression Durbin-Waston (CRDE) test, whose values where first provided by Sargan and Bhargava (1983).

\section{Error Correlation Mechanism (ECM)}

The error correlation mechanism is employed to tie the short-run dynamic behaviours of a variable to its long-run value. The error correlation mechanism (ECM) first used by Sargan and later popularized by Engle and Granger (1987) corrects for disequilibrium.

Given these dynamics, Engle and Grander suggested that adjustments should be involved through the (iterative) process to obtain a more parsimonious model. The ECM is stated as;

$\Delta \mathrm{Yt}=\mathrm{a}_{0}+\mathrm{a}_{1} \Delta \mathrm{X}_{\mathrm{t}}+\mathrm{\alpha}_{2} \mathrm{U}_{\mathrm{t}-1}+\varepsilon_{\mathrm{t}}$

Where $\Delta$ as usual denotes the first differences operator, $\varepsilon_{t}$ is the random error term, and $U_{t-1}=\left(Y_{t-1}-\beta_{1}-\beta_{2} X_{t-}\right.$ 1), this is the one period lagged value of the error from the co-integrating regression.

\section{Unit Root Test Result}

For a guide to an appropriate specification of the regression equation, the characteristics of the time series data used for estimation of the model were examined to avoid spurious regression. We begin by determining the underlying properties of the process that generate out time series variables that is whether the variables in our model were stationary or non-stationary. Macroeconomic data often appear to posses' stochastic trends that can be removed by differencing the variables. We therefore employ the Augmented Dickey Fuller $(\mathrm{ADF})$, to test the order of integration of the variables. 


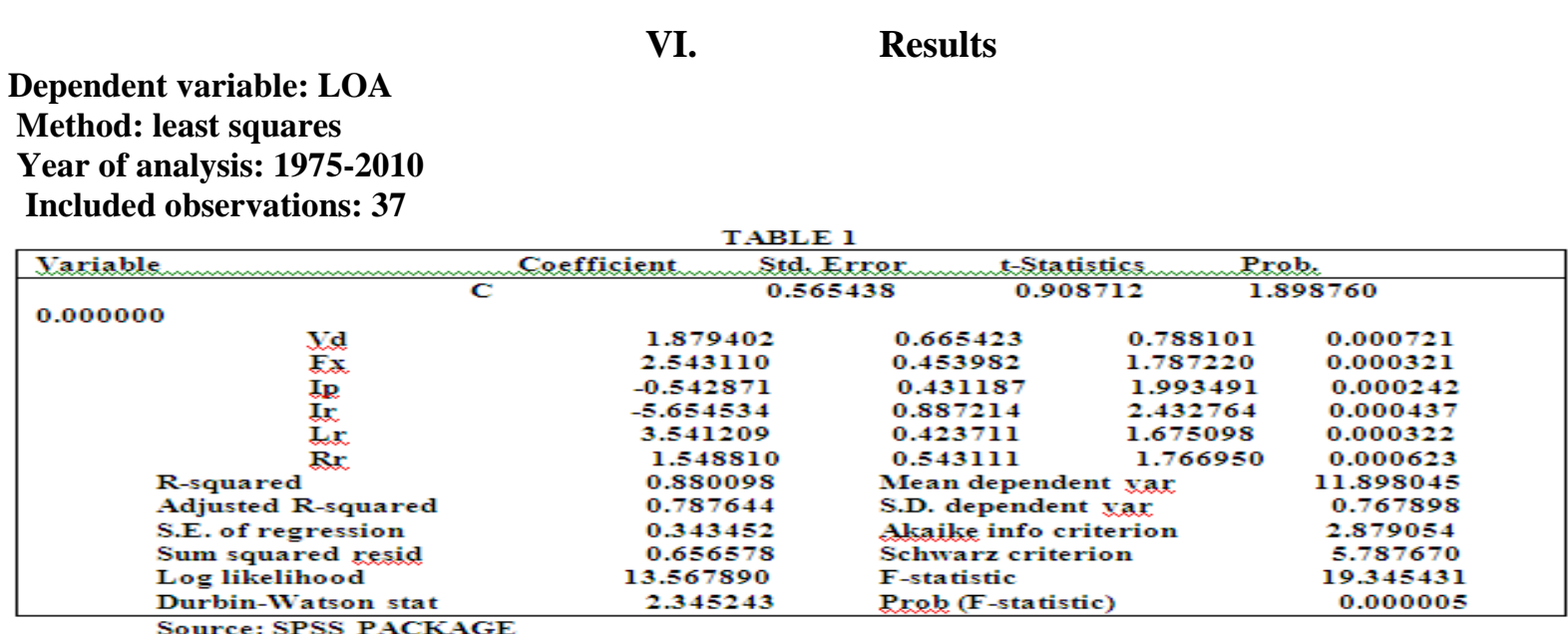

\section{VII.}

\section{Interpretation Of Multiple Regression Result}

The result above shows that there is direct/positive relationship between Commercial bank Loan and advances and Volume of deposit. That is as Commercial bank Loan and advances increases, it leads to an increase in the Volume of deposit and vice versa. However, the coefficient of the parameter Volume of deposit is 1.879402 and it indicates that a $1 \%$ increase in Commercial bank Loan and advances will lead to $-18.79 \%$ increase in Volume of deposit. Moreover, the sign of Volume of deposit conform to our appriori expectation and this shows that as the Commercial bank Loan and advance increases in the economy, a lot of customers will definitely increase their deposit in the bank because they can be considered for loan and advances whenever they apply for it.

However, the t-statistics for parameter Volume of deposit shows that it is statistically significant at 5\% level of significant and this indicate that the parameter Volume of deposit is good explanatory variable.

More so, there is direct/positive relationship between Commercial bank Loan and advances and annual average exchange rate of Naira to dollars. That is as Commercial bank Loan and advances increases, annual average exchange of naira to dollars also increases and vice versa. However, the coefficient of the parameter investment Portfolio is 2.543110 and it indicates that a $1 \%$ increase in Commercial bank loan and advances will lead to $25.43110 \%$ increase in annual average exchange rate of naira to dollars.

Moreover, the sign annual average exchange rate of naira to dollars conforms to our appriori expectation and this shows that as the Commercial bank Loan and advance increases in the economy, annual average exchange rate of naira to dollars also increases overtime. However, the t-statistics for parameter annual average exchange of naira to dollars shows that it is statistically significant at $5 \%$ level of significant and this indicate that the parameter annual average exchange rate of the naira to dollar is a good explanatory variable.

More over, it was also known from the result that there is a negative or inverse relationship between Commercial bank Loan and advances and the lending rate. That is as Commercial bank Loan and advances increases; the lending rate also increases overtime and vice versa. However, the coefficient of the parameter investment Portfolio is -0.542871 and it indicates that a $1 \%$ increase in Commercial bank loan and advances will lead to $-5.42871 \%$ increase in lending rate. Moreover, the sign lending rate conforms to our appriori expectation and this shows that as the Commercial bank Loan and advances increases, lending rate also increases. However, the t-statistics for parameter lending rate shows that it is not statistically significant at $5 \%$ level of significant and this indicate that the parameter lending rate is not good explanatory variable.

Further more, it was also known from the result that there is a negative or inverse relationship between Commercial bank Loan and advances and the liquidity ratio. That is as Commercial bank Loan and advances increases; the liquidity ratio also increases overtime and vice versa. However, the coefficient of the parameter liquidity ratio is -5.654534 and it indicates that a $1 \%$ increase in Commercial bank loan and advances will lead to $-56.54534 \%$ increases in liquidity ratio. Moreover, the sign lending rate conforms to our appriori expectation and this shows that as the Commercial bank Loan and advances increases, liquidity ratio also increases. However, the t-statistics for parameter liquidity ratio shows that it is not statistically significant at $5 \%$ level of significant and this indicate that the parameter liquidity ratio is not a good explanatory variable.

More so, it was also known from the result that there is a direct or positive relationship between Commercial bank Loan and advances and the Liquidity ratio. The implication of this is that as Commercial bank Loan and advances increases, Liquidity ratio also increases overtime. However, the coefficient of the parameter Liquidity ratio is 3.541209 and it indicates that a $1 \%$ increase in Commercial bank loan and advances will lead to $35.41209 \%$ increases in Liquidity ratio. However, the t-statistics for parameter Gross domestic product shows 
that it is statistically significant at $5 \%$ level of significant and this indicate that the parameter Liquidity ratio is a good explanatory variable.

However, it was also known from the result that there is a direct or positive relationship between Commercial bank Loan and advances and the cash reserve requirement ratio. The implication of this is that as Commercial bank Loan and advances increases, cash reserve requirement ratio also increases overtime. However, the coefficient of the parameter cash reserve requirement ratio is 1.548810 and it indicates that a $1 \%$ increase in Commercial bank loan and advances will lead to $15.28810 \%$ increases in cash reserve requirement ratio. However, the t-statistics for parameter Gross domestic product shows that it is statistically significant at $5 \%$ level of significant and this indicate that the parameter Cash reserve requirement ratio is a good explanatory variable.

Furthermore, the $\mathrm{F}$ statistics shows that the overall parameter/models is statistically significant at $5 \%$ level of significant and the R-squared is 0.880098 which gives $88 \%$ and it means that about $88 \%$ variation in the dependent variable has been explained by the independent variable while the remaining $12 \%$ are outside or not present in the model.

VIII. Unit Root Test Result

Table 2: Unit Root Test Result

\begin{tabular}{|l|l|l|}
\hline \multicolumn{2}{l}{ Table 2: Unit Root Test Result } \\
\hline Variables & $\begin{array}{l}\text { ADF } \\
\text { T-Statistic }\end{array}$ & Order \\
\hline LNLOA & -1.434221 & I(1) \\
\hline LDVd & -1.687622 & I(0) \\
\hline LNFx & -1.786632 & I(1) \\
\hline LXIp & -2.443261 & I(1) \\
\hline LNIr & -1.540982 & I(0) \\
\hline LNIr & 2.544380 & I(0) \\
\hline LXRr. & 2.439716 & I(0) \\
\hline
\end{tabular}

The result above in table 2 shows that Loan and advances (LOA), Annual Avearge exchange rate of the naira to dollar (Fx), Investment Portfolio (Ip), are stationary at first difference that is the variables are I(1) series, Volume of deposits ( $\mathrm{Vd}$ ), Interest rate (lending rate) (Lr), Liquidity Ratio ( $\mathrm{Lr}$ ), Cash resrve requirement ratio ( $\mathrm{Rr}$ ) are stationary at levels meaning is an $\mathrm{I}(0)$ series. This is deducted from the fact that for the levels of variables, the absolute values of the ADF statistics are greater than the critical values of the ADF at 5\% level of significance.

IX. Johansen's Co-integration Test Result

The co-integration analysis helps to test for the existence of long run stable relationship that exists between the dependent variable and its regression. A vector of variables integrated of order one is co-integrated if there exist linear combination of variables that are stationary. Following the approach of Johansen and Juselius (1990) two likelihood ratio test statistic, the maximal eigen value and the trace statistic were utilized to determine the number of co-integration vectors.

Table 3: Test of Co-integration

\begin{tabular}{|l|l|l|l|l|l|}
\hline Series & Eigenvalue & $\begin{array}{l}\text { Trace } \\
\text { Value }\end{array}$ & $\begin{array}{l}\text { Percent } \\
\text { Critical } \\
\text { value }\end{array}$ & $\begin{array}{l}\text { 1 percent } \\
\text { critical } \\
\text { Value }\end{array}$ & $\begin{array}{l}\text { Hypothesized } \\
\text { No. of CE(S) }\end{array}$ \\
\hline LNLOA & 0.435180 & 27.06542 & 26.21 & 65.05 & None** \\
\hline LNVd & 0.221877 & 27.67632 & 31.45 & 53.12 & At most 1 \\
\hline LNFx & 0.322871 & 31.07682 & 21.96 & 67.79 & At most 2 \\
\hline LNIp & 0.187230 & 7.54812 & 12.32 & 29.07 & At most 3 \\
\hline LNIr & $2.45 E-04$ & 8.34219 & 4.54 & 4.85 & At most 4 \\
\hline LNLr & $2.67 E-07$ & 21.76290 & 43.36 & 48.73 & At most 5 \\
\hline LNRr & $1.65 E-06$ & 38.54631 & 21.54 & 73.31 & At most 6 \\
\hline
\end{tabular}

$*(* *)$ denotes rejection of the null hypothesis at the $5 \%(1 \%)$ level respectively

Trace test indicates 1 co-integrating equation at both 5\% and $1 \%$ level Table 3 above reveals that the null hypothesis of no co-integration is rejected. This implies that the long run test reveals co-integration relationship among variables that were included. The result also reveals that there is 1 Co-integration 
equation(s) at both $5 \%$ and $1 \%$ levels; this indicates a long run equilibrium relationship between Loan and advances and its explanatory variables (Volume of deposits (Vd), Annual average exchange rate of naira to dollar (Fx), Investment Portfolio (Ip), Interest rate (lending rate) (Ir), Liquidity Ratio (Lr) and Cash reserve requirement ratio $(\mathrm{Rr}))$.

\section{Error Correlation Model (ECM) Result}

We proceed to estimate the short run error correlation model after having reached a conclusion regarding the inherent long run relationships. Hendry's 'general to specific' approach was used to reduce the over-parameterized equation to its parsimonious form.

The results presented in table 6 shows that the model has a good fit indicated by the R squared of 0.5 . The explanatory variables explain 50\% of the variation in Gross Domestic Product (GDP). There is no serial autocorrelation given that the Durbin Watson statistic (2) is within the acceptable bound.

\begin{tabular}{|c|c|c|c|c|}
\hline Variable & Co-efficient & Std. Error & T-Statistic & Prob. \\
\hline Constant & 0.552761 & 0.032417 & 2.128745 & 0.032 \\
\hline D (INV) & 0.532189 & 0.038871 & 1.345207 & 0.098 \\
\hline $\mathrm{D}(\mathrm{I}) \mathrm{F} \times(-1)$ & 0.278640 & 0.054211 & 1.118730 & 0.011 \\
\hline$D(I>I p(-1)$ & -1.762160 & 0.118901 & 2.887611 & 0.054 \\
\hline D(I SIr (-1) & -5.543981 & 0.021221 & 2.435190 & 0.056 \\
\hline$D(I>I)(-1)$ & 4.522145 & 0.345110 & 1.439081 & 0.021 \\
\hline D(I)R $(-1)$ & 2.646760 & 0.121276 & 2.654873 & 0.013 \\
\hline $\operatorname{ECM}(-1)$ & -0.454321 & 0.423427 & -3.333210 & 0.054 \\
\hline \multicolumn{4}{|c|}{$\begin{array}{cc}\text { R squared } & 0.775000 \\
\text { Adjusted R squared } & 0.655000 \\
\text { S.E of regression } & 0.066192 \\
\text { Sum squared resid. } & 20.509181 \\
\text { Log likelihood } & 0.054197 \\
\text { Durbin WVatson stat } & 1.321801\end{array}$} & $\begin{array}{l}0.043981 \\
0.543529 \\
-7.918240 \\
-4.871935 \\
9.335104 \\
0.003241\end{array}$ \\
\hline
\end{tabular}

variable except Investment portfolio and interest rate (lending rate) and all the parameter are statistically significantly at $5 \%$ level of significant except the lagg value of investment portfolio and interest rate (lending rate) that are not significant. In conclusion, the short run to the long run is more significant in the model.

\section{RECOMMENDATION}

\section{Recommendation And Conclusion}

Based on the findings in this study, the following suggestions are recommended

*Commercial banks should develop credit procedures, policies and analytical capabilities and these efforts should be expanded into full credit management including origination, approval, monitoring and problem management tailored to the needs of each bank.

*Commercial banks should strategize on how to attract and retain more deposits so as to further improve on their lending performance.

*There should be closer consultation and cooperation between commercial banks and the regulatory authorities so that the effect of regulatory measure on commercial banks will be taken into account at the stage of policy formulation.

*The cost associated with lending to priority sectors as a national goal, should be borne by the society as a whole through the government budget instead of burdening the commercial banks with such cost. This is necessary because the commercial banks cannot afford to overprice or under price their loans for efficient lending performance.

*Nigerian commercial banks should ensure good planning which encompasses budgeting, reviews and incentives. They should formulate critical, realistic and comprehensive strategic and financial plans. This will help them be better positioned to enjoy the positive effects of macroeconomic factors such as change in gross domestic product and foreign exchange in a volatile environment such as Nigeria economy. *It is essential for commercial banks to build system and skills in liquidity management, assets and liability management and foreign exchange management. *Banks should try as much as possible to strike a balance in their loan pricing decisions. This will help them to be able to cover cost associated with lending and at the same time, maintain good banking relationship with their borrowers.

\section{Conclusion}

Commercial banks remain dominant in the banking system in terms of their shares of total assets and deposit liabilities. Their total loans and advances, a major component of total credits to the private sector are still on the increase in spite of the major constraints posted by the government regulations, institutional constraints and other macro economic factors. However, both government and commercial banks should be mindful of the facts that the environments in which they operate are important factors in the bank performance 
and behavior. Where the environment is conducive and supportive, performance is enhanced and good lending behaviour guaranteed. But where the environment is unstable and harsh, the bank's performances suffer. Commercial banks should note that they need to do a lot in order to ensure good lending behaviour even where a good measure of macro economic stability is achieved. It therefore follows that effort should be made by commercial banks to enforce the most easily realizable policies and good credit management in every situation.

\section{References}

[1] Adedoyin and Shobodun (1991) Lending in Banking Business, Problems and Prospect, $3^{\text {rd }}$ edition, pg 23-34, Saiye Printers, Lagos.Agu C.C (1988) Nigerian Banking structure and performance, the banking system contributes to economic Development, Studied. Onitsha African FEP Publishers.

[2] Ajayi D (1978) Deposit Rates in a deregulated Regime and its implications, vol 3, pg 55-67, University Press limited.Akpanuko and Acha, (2010). 'Instability in the Banking industry; Is Dynamic

[3] Provisioning a leeway, the Nigeria Journal of Management Research, 5 (i), Pg 40- 50.

[4] Amassoma, Massona J.D, Nwosu PI, and Ofere A.F, (2011) The nexus of interest rate deregulation, lending rate and Agricultural Productivity in Nig, Project for Dept of Econ, Joseph Ayo Babalola University, Ikeji Arakeji, Osun State and the Bell University Abeokuta. Ogun State both in Nigeria.

[5] Alhanusoglou, Panayiotis P., Delis, Mathaaos D. and Sikoras Christos K (2008) Determinants of bank Profitability in South Eastern European Regional - MPRA Paper no 10274 Posted 03. September.

[6] Acha, G. (2011) Does bank financial intermediation cause growth in developing Economies, the Nigerian Experience, Interbond business and Management, 3 (1) Pg 156-161.

[7] Bagehot S. (1983) Profitability and its implication, $2^{\text {nd }}$ edition, pg 44-57 Homewood: Richard Irvin Publication. BOFIA (1998) Requirement for Investment and Lending behaviour in Nigeria banking industry.

[8] Buckle and Thompson (1998) The UK Financial system $3^{\text {rd }}$ edition London Manchester University Press.

[9] Bhattacharya and Thakur (1993), Mishkin \& Eating (1998), Buckle \& Thompson (1998) and Saunder \& Cornet (2006), Diamond and Dybvig (1998) Impact of Financial intermediary and Loan disbursement in Commercial bank, Journal of college of Management Science, vol 9, issue 7, pg 32-46, Macgraw Publication limited.

[10] Carletti at al (2006), Ongene \& Smith (2000), Karet et al (2004), Dgreyse et al (2004) Banking Reform in Nigeria, $1^{\text {st }}$ edition, pg 33-51, Mill stone Publication.Chizea G (1994) Analysis of Monetary and Fiscal Policies, broader perspectives, $2^{\text {nd }}$ edition, pg $12-$ 24, BBT Press.

[11] Chodecal D (2004) Impact of lending policy on banking industry in Nigeria, Journal, vol 7, pg 12-22, Unity Press limited.Danis and Zhu (2005) commercial property price and bank performance, bank for International Settlement Press and Communications $\mathrm{CH}$ 4002 Based, Switzerland, (working paper) No. 175.

[12] Davis and Zhu (2005) Commercial Property Price and bank Performance, vol 33, pg 11-23, World Press.

[13] Engle R.F., and Granger, C.W.J. (1987) "Co-integration and Error Correlation: Representation, Estimation and Testing" Eonometrics, Vol. 55 251-276

[14] Ezirim F (2005) Impact of bank Lending on liquidity of banks in Nigeria, Journal vol, 2, pg 44-56, IJJS Publication.Ewert et al (2000) Analysis of Credit Marketing theory, a larger perspective, $1^{\text {st }}$ edition, pg 13-21, Unity Press limited.

[15] Fry.M.1989. Foreign debt instability: An Analysis of national savings and Domestic Investment Response to Foreign Debt Accumulation in 28

[16] Development Countries, Journal of College of Social and Management Science, vol 6, pg 65-89, Mill Publication limited. Grupta, K,L, (1970) Determinants of local and urban household savings, behaviour; the economic record. The society of Austrialia, 46(116), 378-383,

[17] Macgraw Hill Publication. Goldfeld and Chandler (1980) Lending behaviour of Commercial bank, $2^{\text {nd }}$ edition, pg 55, Macmillan Publication.

[18] Godlewski \& Ziane (2008) Firm theory of Loan and advances, $2^{\text {nd }}$ edition, pg 77-80, kent Publication limited.Hansen, H. and J. Rand (2006), "On the Casual Links between FDI and Growth in Developing Countries", World Development 29, 21-41.

[19] Haron S (2004) Analysis of Financial Statement of commercial in Sweden, $2^{\text {nd }}$ edition, pg 44-51, Melt world Publication. Itiwe T. (1983) Elements of practical Banking, a textbook $2^{\text {nd }}$ edition, pg 37-41,

[20] Ibadan, University Press. Johasen and Juselius (1990) Introduction to Co-integration analysis, $2^{\text {nd }}$ edition, Pg 33- 51, Machill Publication.

[21] Keen G. (2009) The Dynamics of money circuit and the political Economy of Money circuits, Tradition and change in Post Keynesian Economics, Edited by Jean- Francois Ponsot and Sergir Rossi (pp.161-187) Palgrare Macmillian, 08-07-2009.

[22] Naceur and Goaid (2010) Determinants of commercial bank in Nigeria, vol 5, pg 19-29, Macmillan Publication limited.Mckinon, R. (2005) Money and Capital in Economic Development, $1^{\text {st }}$ Edition, pg 55-64, Banking Institution, Wahington DC. USA Publication.

[23] McKinnoh J. (1993) Money and Capital in Economic Development, $3^{\text {rd }}$ edition, Pg 33-54 Washington Dc; the Booking Institution. Ojo D. (1999) Roles and failures of financial intermediations, by banks CBN Bullion, 23(3), pp 10-12.

[24] Olokoyo A. (2011) Determinants of commercial banks lending behavior in Nigeria. International Journal of financial Research vol2, Pg.61-62.

[25] Osayameh F. (1991) Lending and credit administration model for commercial banks, Nigeria Financial Review, 4(2) pg 55-60

[26] Rhrawish, Husin, Mohammed Al-Abadi and May soon Hejazi, Determinants of banks not int. rate margin: Eudence from Jordan, Jordan Journal of Biz Administration, Volume 4, No 4, 2008 PP185-205.

[27] Samad. Abdus, (2004) Bahrains Commercial bank performance as during 1994- 2001, Credit and Financial Management Review (working paper) Sargan and Bhargava (1953) Introduction to co-integration analysis, $1^{\text {st }}$ edition, pg 34-45,

[28] Machill Publication limited. Schumpeter D. (1984) Theory of Economic Development, $2^{\text {nd }}$ edition, pg 22-32 Cambridge: Harvard University Press.

[29] Stiglitz and Weiss (1991) Analysis of Loan and disbursement in the Commercial Bank, $2^{\text {nd }}$ edition, pg 44-49, Macgraw Hill Publication limited.Uhomoibhi, T (2008) Determinants of Bank profitability macroeconomics, Evidence from Nigeria, Deakin University, (Working paper).

[30] Usman J. (1999) Bank regulatory and supervisory in Nigeria, the Nigeria Banker bullion pg 7-9.

[31] Von T (2004), Padilla \& Pagano (1997) Loan and advances in a Financial institution, $2^{\text {nd }}$ edition, pg 24-27, west point Press.

[32] Williams, E, (2009) The Return of interest rate caps, business world Publication, May 17. 